\title{
Composition and Shape of Hadrianic Domes
}

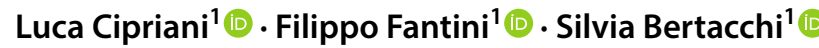

Published online: 1 August 2020

(c) The Author(s) 2020

\begin{abstract}
In-depth studies on the design of the domes of the Octagonal Hall of the Small Baths and the Vestibule of the Golden Court at Hadrian's Villa in Tivoli have been conducted starting from 3D surveys carried out with active and passive sensors. Through the comparison of the ichnographia and orthographia of these emblematic examples of architectural experimentation, common elements and features have emerged which, thanks to the integrated use of new measurement technologies, have allowed us to hypothesise dimensioning systems of the vertical structures together with possible criteria for defining the intrados-extrados relationship. Hadrian's architects' use of precise grid-based designs to facilitate the achievement of target quantities (required areas and volumes) as well as modules aimed at defining alignments of horizontal and vertical structures emerge clearly, providing useful elements for an integrated reading of the individual buildings to support the archaeological investigation.
\end{abstract}

Keywords Complex vaults $\cdot$ Hadrianic domes $\cdot$ Hero of Alexandria $\cdot$ Vitruvius . Hadrian's villa

\section{Aims of Recent Surveys}

Under the supervision of the Istituto Autonomo Villa Adriana e Villa d'Este, several surveying campaigns have been carried out with the aim of shedding more light on a number of issues between archaeology and architecture of the Hadrianic mansion (Cipriani 2018). The research outcomes presented here have been in development since 2013. These studies involved buildings characterised by curvilinear

Filippo Fantini

filippo.fantini2@unibo.it

Luca Cipriani

luca.cipriani@unibo.it

Silvia Bertacchi

silvia.bertacchi@unibo.it

1 Department of Architecture, Alma Mater Studiorum, University of Bologna, Bologna, Italy

Birkhäuser 
entablatures present in the most luxurious pavilions of Hadrian's Villa: Maritime Theatre, Golden Court, Serapeum-Canopus Complex, Temple of Venus Cnidia, Small Baths, Accademia and Imperial Palace.

The aim is to reconstruct the system of geometrical rules for designing plan and elevation, consistently with the limited number of formulas that ancient architects applied to define the building and its parts. Consequently, efforts have been made to clarify the relationship between central-plan halls and the buildings they belong to: this is why we extended the focus to the whole building, not just to its domes. A specific interest for a certain part of the complex has often prevailed in previous research by renowned authors, as in the case of the Golden Court, which boasts numerous particular studies, but lacks an overall reading starting from recent surveys. ${ }^{1}$

As is in the case of Baiae, near Naples, Hadrian's Villa offers countless variations of the octagonal theme, whether it is included in sequences of adjacent volumes, or even as an added element to more traditional and regular compositions. Through the comparison of octagonal halls, and their mixtilinear derivations, common elements emerge, not only in stylistic and technological terms, but more properly in layout definition, that is, the ancient compositional technique including modularity, equivalence of surfaces and volumes, and simple proportionality in the planelevation ratio. In this respect, it should not be forgotten that many of the previously mentioned buildings included real prototypes of domes, some of which can be compared to the so-called "umbrella" typology, or even complex derivations of cloister and groined vaults, showing Hadrian's desire to encourage original solutions. The newly conceived domes, such as those of the Octagonal Hall of the Small Baths (Fig. 1) and the Vestibule of Golden Court (Fig. 2), are largely preserved and still provide a vivid image of the formal originality present in the Villa.

The design analysis aims at achieving more reliable reconstructive hypotheses and completions of these prototypes: hardly comparable to more canonical solutions in the Roman world, actually similar cases can be found in few other places of imperial rank. For this reason, larger and unusually shaped pavilions led to substantially different interpretations among scholars, ${ }^{2}$ with the consequence that today there is still uncertainty regarding the design of vaulted structures of the Golden Court and Accademia's Mixtilinear Atrium. Hence the need for further and in-depth surveys for exact comparisons with buildings or parts of them in obvious relation: the aim is to go beyond the morphologic study of the intrados surfaces alone, insufficient for understanding the overall design of the so-called Hadrianic "pumpkins" (Adembri

\footnotetext{
${ }^{1}$ On this topic see (Slavazzi 2014): while proposing an overall reading of the building, together with an accurate bibliography, the author does not deal with the description of the building in the terms proposed here, i.e. the understanding of the dimensional relationships between plan and elevation of each pavilion through geometrical schemes and ancient measurements. The present paper is consistent with the schematisations in (Hansen 1960) and (Rakob 1967) and, more recently, (Ottati 2017) and (Ottati et al. 2018).

2 The reference is to the well-known debate among eminent scholars with opposing positions regarding the vaulted space of the southern Octagonal Hall of the Golden Court and the so-called Mixtilinear Atrium (Moneti 1992).
} 


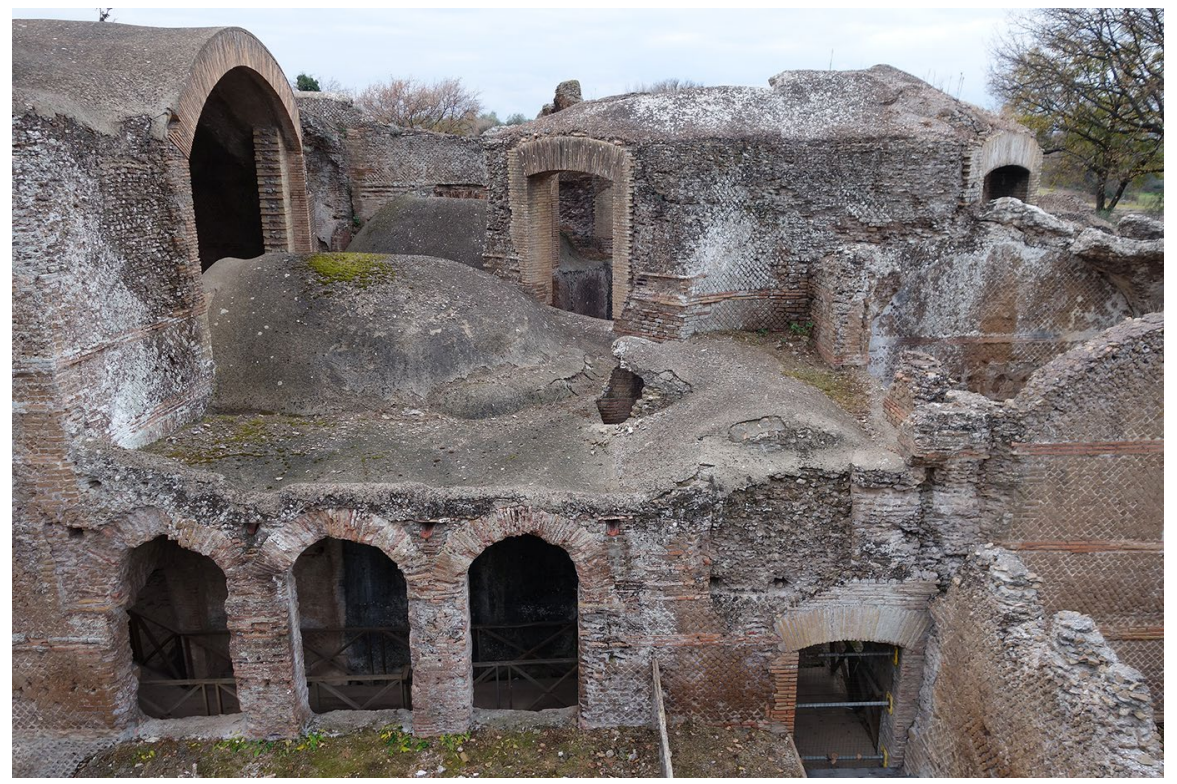

Fig. 1 Small Baths view from East. Photo: Filippo Fantini

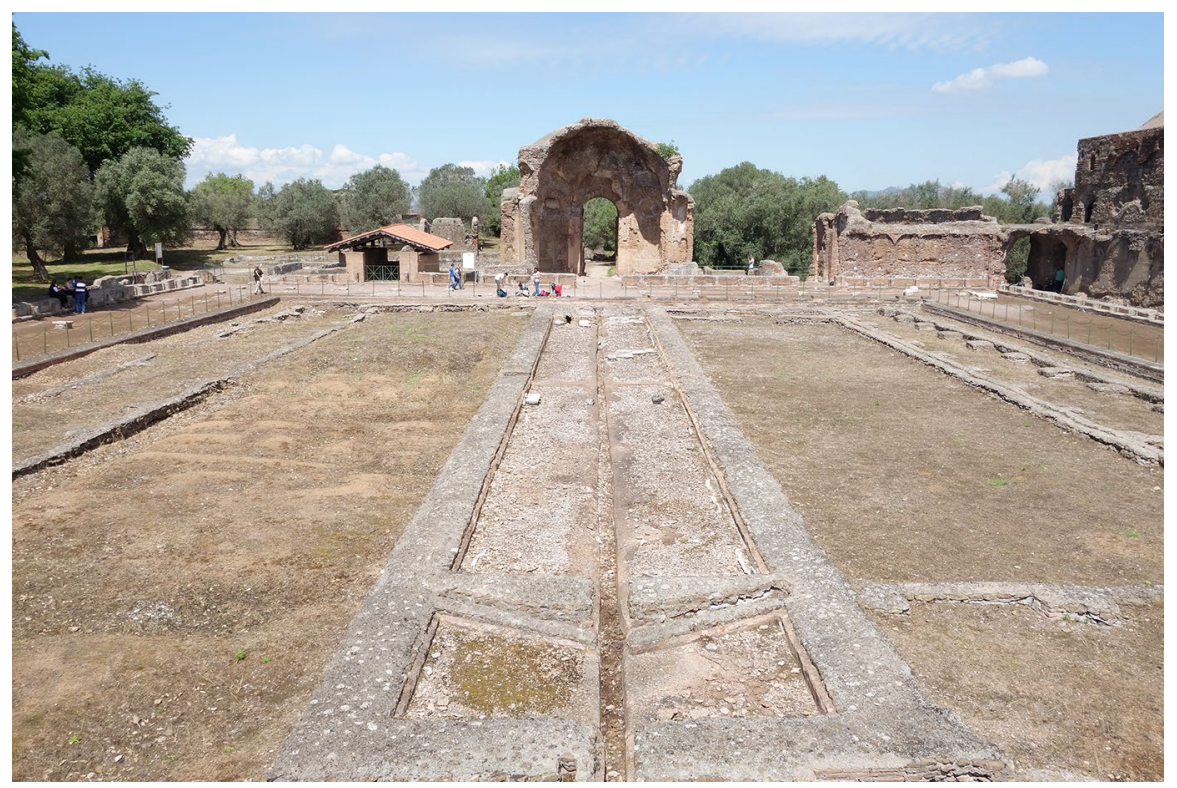

Fig. 2 Vestibule of the Golden Court. Photo: Filippo Fantini

et al. 2016: 303-308). Surveys have been completed gradually, also including less documented areas in earlier explorations of the Villa. This has made it possible 


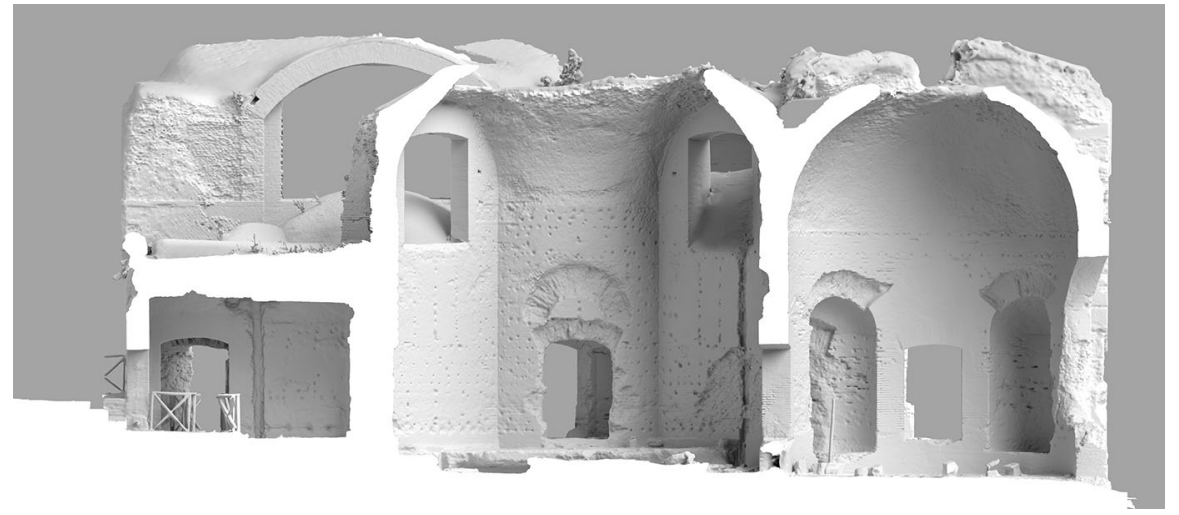

Fig. 3 Longitudinal section of the Small Baths. Note the morphological complexity of the extrados, the subject of specific surveys aimed at understanding the exact thickness

to distinguish original from restored areas - these latter often carried out with construction procedures imitative of ancient techniques - and to "extract" shapes presumably closer to the original geometries that guided the positioning of centrings and the definition of intrados and extrados (Fig. 3).

As general statement and according to the current state of acquired dataset, the compositional nature of opus caementicium vaults still seems unclear, but is far from being reduced a single "umbrella" typology. On the contrary, it is possible to affirm that extremely articulated plans probably ended in spherical caps. At Hadrian's Villa and Baiae, certainly also in Rome (e.g. the lost Temple of Siepe and Horti Sallustiani) and Viterbo (Baths of Bacucco), architects had to deal with complex formal problems, whose solution would be gradually found in different building typologies through significant reinterpretation during late Antiquity, and then rediscovered starting from the Renaissance. Such prodromes are subject to a significant precariousness: they present authors' changes of minds, as well as conditions of fragility arising from their nature of "prototypes". For these and other reasons, Cassius Dio reported severe criticisms of Hadrian's pumpkin-shaped domes by the architect Apollodorus of Damascus (Brown 1964).

\section{An Increasing Will to Experiment}

The two domes analysed in this study are included within the category of structures covering octagonal plans and their mixtilinear derivations; therefore we will not deal with vaulted solutions covering circular plans, except for specific reasons. ${ }^{3}$ Although there is no unified position among scholars, it is reasonable to say that Hadrian's

\footnotetext{
${ }^{3}$ On typological distinction of vaulted spaces based on the circular or octagonal plans, see De Angelis D’Ossat (1938: 13-15).
} 


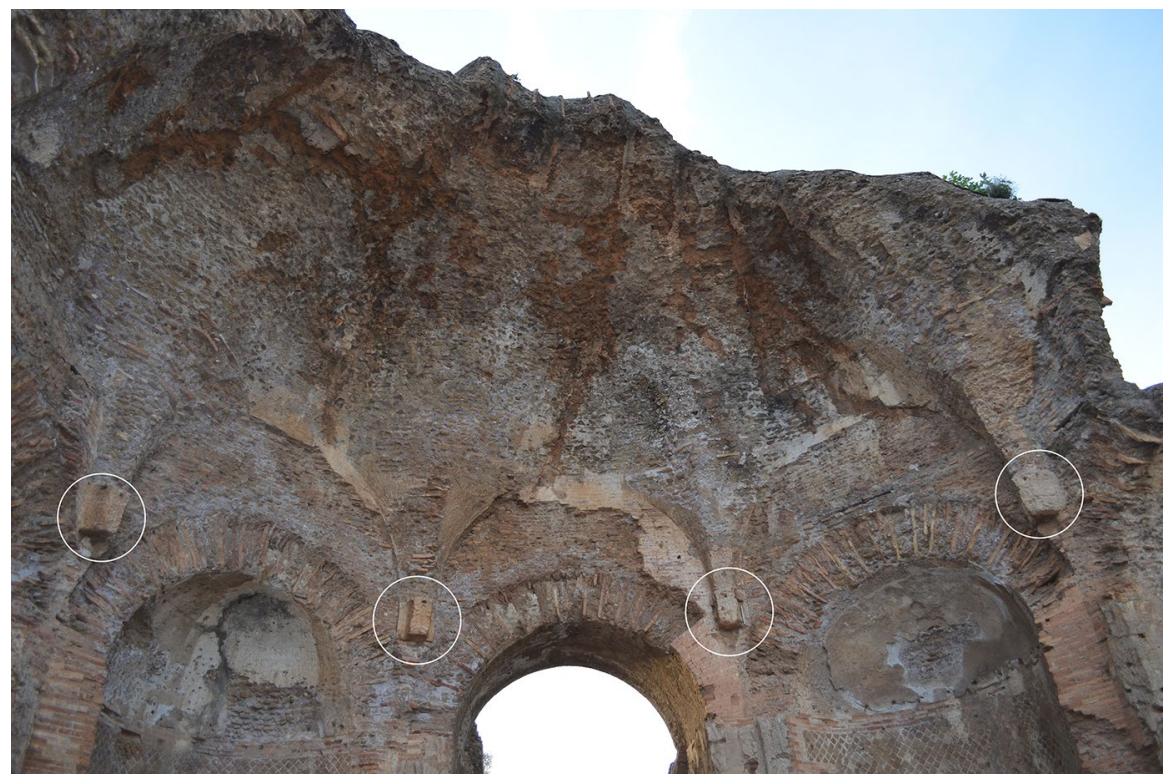

Fig. 4 Vestibule of the Golden Court. Huge travertine blocks act as corbels for the dome made of bricks and opus caementicium. Photo: Filippo Fantini

Villa was built in two main phases (118-121 A.D.; 124-128 A.D.), followed by further interventions of various kinds. In this context it is possible to observe an increasing structural and formal complexity as building progressed from the north to the south.

In the first construction phase there is no case of structural lightness akin to that of the Octagonal Hall at the Domus Aurea, whose thickness is around a Roman foot (1 Roman foot $=29.56 \mathrm{~cm}$ ), or even of extrados domes: in fact internal and external profiles do not match in any of the examples of the initial building development. We are also able to find technological solutions in line with previous examples by Trajan, where huge travertine blocks act as corbels for monumental cross vaults, as can be appreciated in the Villa's Greek Library. These travertine elements are incorporated into the masonry, sometimes even passing through the walls, and had the clear functions of strengthening the supporting base of vaults, and of concentrating the mechanical stress produced by the loads towards the abutments. Remarkable examples of this technique can be found in the frigidarium of the Great Baths, in the Vestibule of Golden Court (Fig. 4), and in many other cases (Maritime Theatre, Golden Court) in which the mixtilinear entablatures are embedded inside the walls.

In other cases, as in the Small Baths, it seems that the architects intentionally avoided the use of travertine to solve structurally complex situations. With very few exceptions, in this thermal building we have an almost exclusive use of opus mixtum and opus testaceum acting as support for very thin domes in opus caementicium lightened by tufelli (tuff elements). The thickness here decreases to only one Roman 
foot (RF), a sort of experimental test aimed at evaluating, in a building with reduced dimensions, the strength of both materials and geometry. Giuseppina Cinque and Elisabetta Lazzeri (2011: 62-63) suggested that the ichnographia of the Summer Triclinium at the Imperial Palace was a former and smaller version of the SerapeumCanopus complex; that is, structurally complex buildings of the second phase of the Villa may have been inspired by the experiments with preliminary models on a smaller scale.

\section{Approach to the Problem}

For the purpose of this present investigation highly detailed 3D digital models of the buildings are the primary requirement (sampling step variable from 4 to $8 \mathrm{~mm}$ ); in addition, this method implies a complete survey, not just limited to the vault and surrounding structural elements. In other words, what we may find in the dome (modular relations and ratios, etc.) must be related with the whole building design. To repeat the steps of the design process carried out by the original architect, a specific workflow had to be developed, based on the use of reverse modelling applications in combination with the hints from the limited amount of surviving technical literature regarding vaults and domes of the Roman world. Giangiacomo Martines (2015: 99-131); Conti and Martines (2010), Svenshon (2009) and Cipriani et al. (2017) are among the works focussed on linking the results of accurate surveying techniques with the only existing ancient texts regarding design techniques for arches and vaults: they all refer to the seminal, but partially forgotten, Heronis Alexandrini, Opera quae supersunt omnia (Heiberg 1914), a comprehensive translation of and noteworthy commentary on the writings from the Greek mathematician. No one else could have approached the problem presented by these writings with the same awareness of Johan Ludvig Heiberg, who was able to handle the field of Greek and Latin literature as well as to deal with mathematics and engineering problems. The Danish philologist was also responsible for a major discovery: a vellum manuscript of Archimedes writings that he found in Constantinople in 1906, unknown to scholars at that time, the so-called Archimedes Palimpsest. As reported by Boyer (2000: 163-164), the manuscript, formed by 185 folia (the majority written on parchment), was a tenth-century transcription including several treatises by the Syracusan mathematician, among them Spiral Lines, Measurement of a Circle and On the Sphere and Cylinder. This last writing is of great importance for the purposes of designing an analysis method on vaulted spaces since it includes the well-known formula for calculating the volume of a sphere (V):

$$
\mathrm{V}=\frac{4}{3} \pi \mathrm{r}^{3}
$$

Among the technical terms used by the Syracusan mathematician is one also present in Vitruvius's design theory: symmetria (Bianchini and Fantini 2015: 
28-29). ${ }^{4}$ With this word Archimedes identifies the property of commensurability expressed in certain shapes such as circle, cone, sphere, and cylinder. For Vitruvius symmetria was a quality of a properly designed architecture: he meant that areas of different parts or elements of a building had to be commensurable, namely linked by simple ratios such as 1:1, 1:2, etc. This quality was achieved through a series of calculations that, in a certain way, aimed to simulate the "natural ratios" present in geometric shapes, discovered by Archimedes, then developed by other mathematicians in further studies, frequently in form of commentaries applied to the resolution of practical problems, as in the case of Hero of Alexandria. ${ }^{5}$

The application of the set of formulas coming from On the Sphere and Cylinder to the field of architecture may have been dealt with in a lost treatise entitled $O n$ Vaulting by Hero of Alexandria (Martines 2014: 279; Cipriani et al. 2017: 438).

Even though we can just suppose the contents of this work, it is safe to say that other survived manuals by Hero may include - albeit not systematically — the same problems present in On Vaulting (Svenshon 2009: 1389). This aspect is common to other writings by Hero as in the case of determining the seating capacity of theatres (Bianchini and Fantini 2015: 32-36): in De mensuris I.24 "Measurement of theatres" and Stereometrica I 42 "Different way for calculating basins", Hero uses different numerical examples, but the algorithm to achieve the number of spectators is the same:

$$
\mathrm{N}_{\mathrm{s}}=\frac{\mathrm{E}_{\mathrm{s}}+\mathrm{I}_{\mathrm{s}}}{2} \mathrm{R},
$$

where $\mathrm{N}_{\mathrm{s}}$ is the number of spectators, $\mathrm{E}_{\mathrm{s}}$ is the length of the external semicircle shaping the cavea in Roman feet, $I_{s}$ is the length of the internal semicircle and R is a scalar number, namely the number of rows of steps. One Roman foot is the seating width allotted for each spectator.

Even if Eq. (2) makes it possible to determine a scalar quantity (spectators), it appears to be a case of squaring the circle, which is also present in other formulas inside Stereometrica. ${ }^{6}$ Similarly, by transposing these considerations into three dimensions, we can see how to obtain the volume of a hollow sphere, using the intermediate surface multiplied by the thickness. As quite rightly pointed out by Helge Svenshon (2009: 1389), it is frequently seen that when an arch or dome has to be calculated, Hero uses numerical examples in which $\pi$ is expressed by a fraction $(22 / 7)$ or by an addition $(3+1 / 7)$. To ease the calculations of circumferences, surfaces, and volumes, namely, to simplify the denominator of the fraction, he uses values of the radius or diameter multiple of 7 . This subject is of importance for our purposes: when studying Roman domes, the presence of

\footnotetext{
${ }^{4}$ Vitruvius lists six terms (I.II.1-9), all coming from the ancient Greek lexicon on architecture, forming the basis of ancient construction theory: ordinatio $(\tau \alpha \xi \downarrow \sigma)$, dispositio ( $\delta 1 \alpha \vartheta \varepsilon \sigma \mathrm{v})$, eurythmia, symmetria,

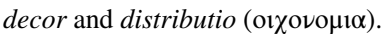

${ }^{5}$ Attilio Frajese (1974: 23) expresses with great efficacy the astonished enthusiasm that characterised Archimedes when he grasped these perfect ratios using the term 'marvel' ( $\theta \alpha v \mu \alpha \dot{\zeta} \varepsilon v v)$.

${ }^{6}$ See Stereometrica, II, 29, translated and graphically commented in Cipriani et al. (2017: 440-443).
} 

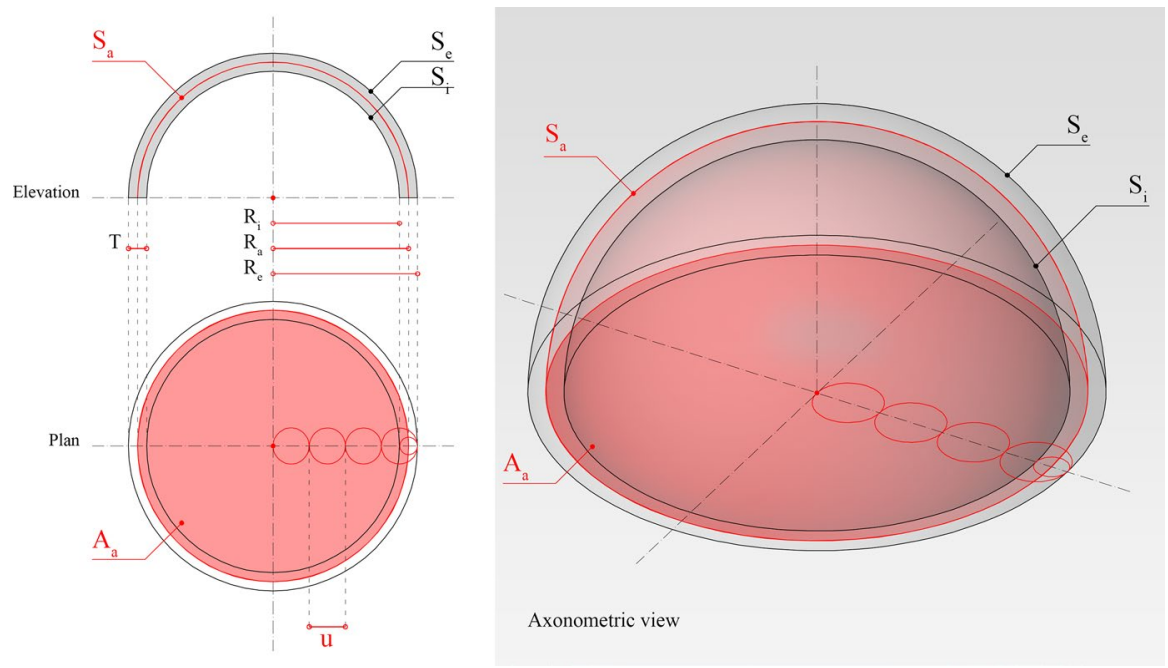

Fig. 5 Scheme of the calculated volumes for the hollow sphere

an integer number of Roman feet, or an integer number of modules, that somehow presents the value 7 should be noticed. The starting point when carrying out the "reverse designing" of such a structure has to take into account the following steps:

- Detection of a modular grid: this feature is common to the whole building to which the dome belongs and, in general, the area of each square facilitates further calculations, being in relation with Latin standard areas. The grid can be detected looking at sequences of structural elements, such as columns, niches, windows: the distance between their axes is in general a first hint to understand the grid-based design of Roman buildings.

- Identification of the main radii of the domes (Fig. 5): intrados $\left(\mathrm{R}_{\mathrm{i}}\right)$ and extrados $\left(R_{e}\right)$. This aspect is far from being simple since restored buildings present heavy coats laid upon the extrados, generally made of cocciopesto (lime mortar with crushed pottery), while intrados may present concrete integration in combination with reinforcement steel bars: all these elements can mislead the interpretation of a reliable digital survey. For this reason, it is safer to carry out an iconographic research to be compared to detailed outputs achievable through digital models: contour lines may present here and there some original elements to be used in further steps of the analysis.

- Calculation of the average radius:

$$
\mathrm{R}_{\mathrm{a}}=\frac{\mathrm{R}_{\mathrm{i}}+\mathrm{R}_{\mathrm{e}}}{2} .
$$

- Determination of the dome's thickness, T.

- Calculation of the average circle area: 


$$
A_{a}=\pi r^{2}=\frac{22}{7} R_{a}^{2}
$$

- Calculation of the average surface of the half-sphere, $S_{a}$, namely the double of $A_{a}$ (according to Archimedes):

$$
\mathrm{S}_{\mathrm{a}}=2 \mathrm{~A}_{\mathrm{a}} .
$$

- Calculation of the dome's volume, $\mathrm{V}_{\mathrm{c}}$ :

$$
\mathrm{V}_{\mathrm{c}}=\mathrm{S}_{\mathrm{a}} \mathrm{T} \text {. }
$$

This scheme of interpretation is not intended to provide an exact key for the analysis of all the domes, but these passages are consistent with the ancient architect's operating methods and, if more specific writings on the subject should emerge, they would not lose their validity. What is certain is that the horizontal sections of domes progressively changed their shape, and from a certain height, mixtilinear profiles blended harmoniously into circles. The hypothesis we advance is that Hero's On Vaulting, after the introduction of basic formulas to calculate regular shapes, may have included solutions to more complex problems, namely approximate calculations for increasingly articulated volumes (including elements of connection between octagons and spheres). ${ }^{7}$

\section{From Survey to Design: Differences and Common Features}

Designing activities in ancient times were not rigidly split into architectural design, structural project, construction logistics, etc. There is abundant literature on this subject (Wilson Jones 2000); but in this case, we are focussing on two concepts/terms forming the species dispositionis: ${ }^{8}$ ichnographia and orthographia. Ichnographia was a technique, or expression, in plan of reliable and multipurpose geometric patterns, aimed at defining building layouts: it solved functional, distributive, structural and constructive problems. Orthographia was a technique in which, starting from the plan, the elevation was determined through precise ratios, modules, and geometric patterns.

Architects applied geometric patterns for the general definition of layouts and facades. Then, having produced irrational quantities through the use of the compass, they had to make them fit into finite quantities for two reasons. The first was for the achievement of simpler calculation of areas and volumes for the metric estimations; the second was the ancient custom of using grid-based designs to facilitate practical

\footnotetext{
7 Examples of this type can also be found in Stereometrica (II, 28 and 30) where we find approximate formulas for calculating the volume of more complex sets including domes, niches, and box-like masonry.

${ }^{8}$ Dispositio has three species: ichnographia, orthographia and scaenographia. For further analysis of these terms see (Adembri et al. 2015).
} 


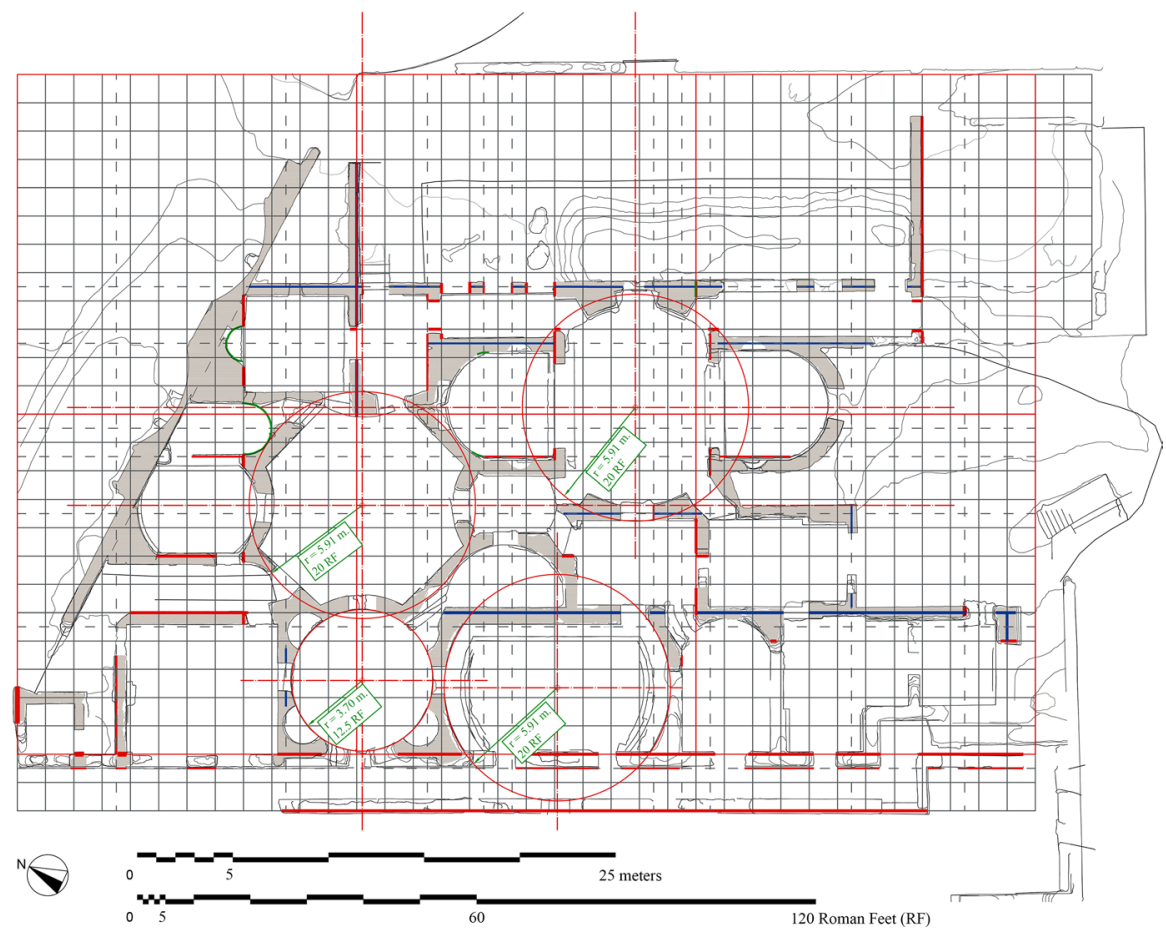

Fig. 6 Grid-based design of Small Baths

issues in the construction process. In the case of Small Baths at Hadrian's Villa, Erik Hansen (1960) and Friedrich Rakob (1967) identified the presence of a modular grid of 5 Roman feet applied to define the internal profile of the Octagonal Hall.

Their key to reading the architecture supposed that ancient builders used a square made of $7 \times 7$ modules for the internal dimensioning of this hall, while the bending radius of the curved sides was of 15 Roman feet. ${ }^{9}$ In Fig. 6 we applied the same modular structure to the whole building. The grid is used as a flexible tool: walls are alternatively aligned to the grid using their centres, interiors or exteriors surfaces depending on the situation.

Due to the state of conservation of masonry and the presence of restorations in the Octagonal Hall, it is necessary to introduce several cutting planes in order to intersect original elements and analyse the best-fitting circumferences, which may lead to inappropriate results if strictly considered from the mere numerical point of view (Fig. 7a).

The main problem deals with the high dispersion around the average value (Table 1), shown graphically in Fig. 7b.

\footnotetext{
${ }^{9}$ Cipriani et al. (2017: 447-448) demonstrated that this hypothesis on the radii of curvature was not consistent with the information obtained from recent instrumental measurements. A new hypothesis will be set out in "Conclusions".
} 


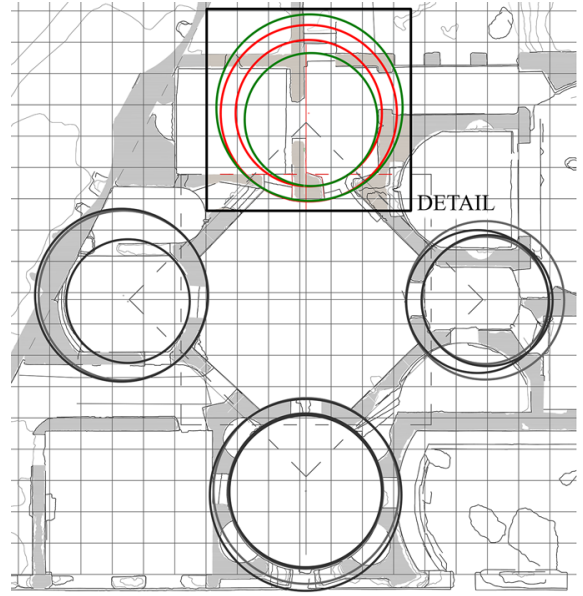

(a)

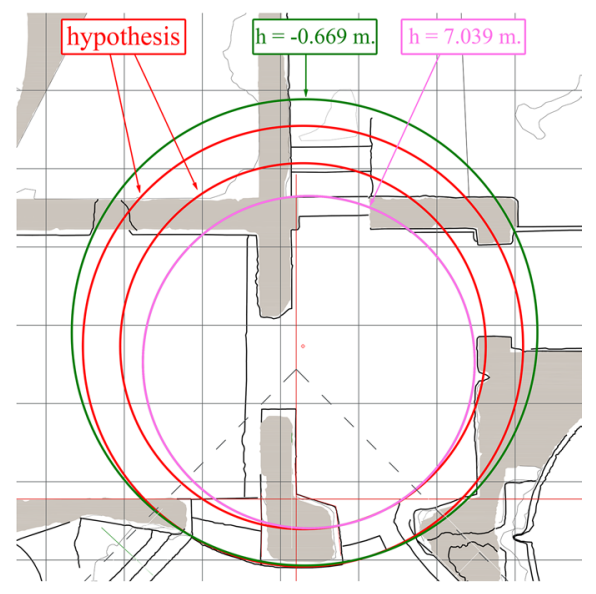

(b)

Fig. 7 a Grid-based design of the Small Baths and best-fitting circles extracted on curved sides at different heights; $\mathbf{b}$ the detail underlines how, at different heights $(\mathrm{h}=-0.669 \mathrm{~m}$. and $\mathrm{h}=7.039 \mathrm{~m})$, extracted circles present high eccentricity

Table 1 Internal best-fitting circumferences extracted by means of 3D Systems Geomagic Design $\mathrm{X}$

\begin{tabular}{lll}
\hline Side & Metres & Roman feet \\
\hline North & 4.04 & 13.66 \\
East & 4.27 & 14.44 \\
South & 3.81 & 12.88 \\
West & 4.35 & 14.71 \\
Average & 4.12 & 13.92 \\
\hline
\end{tabular}

In the Octagonal Hall of the Small Baths the layout is evidently asymmetrical. The reason cannot be simplistically reduced to lack of accuracy of builders, due to the hectic progression of the construction. A geometric pattern was present, but in the final construction phase it was partially ignored. To find a key to reading to this problem, William MacDonald and Bernard Boyle (1980) pointed out how daring was the choice to pierce the walls of the mixtilinear octagon with seven "holes" (Fig. 7a), corresponding to as many doors or passages, located in a non-symmetrical way.

Only the corners are not touched by "material subtractions" since they work as pillars whose thickness is equal to 2.5 Roman feet: the straight walls look like diaphragms, with variable thicknesses due to the presence of the volumes of voids that "erode" very thin walls. But the east-north-east corner is weaker than the others (Fig. 7a). Here the straight wall is thickened up to 3 Roman feet, probably a precautionary measure taken by the architects. They avoided the risk of weakening one of the pillars by altering the symmetry of the structure. Regarding orthographia, one can say that the architect applied a simple ratio to the dimensioning of interior 


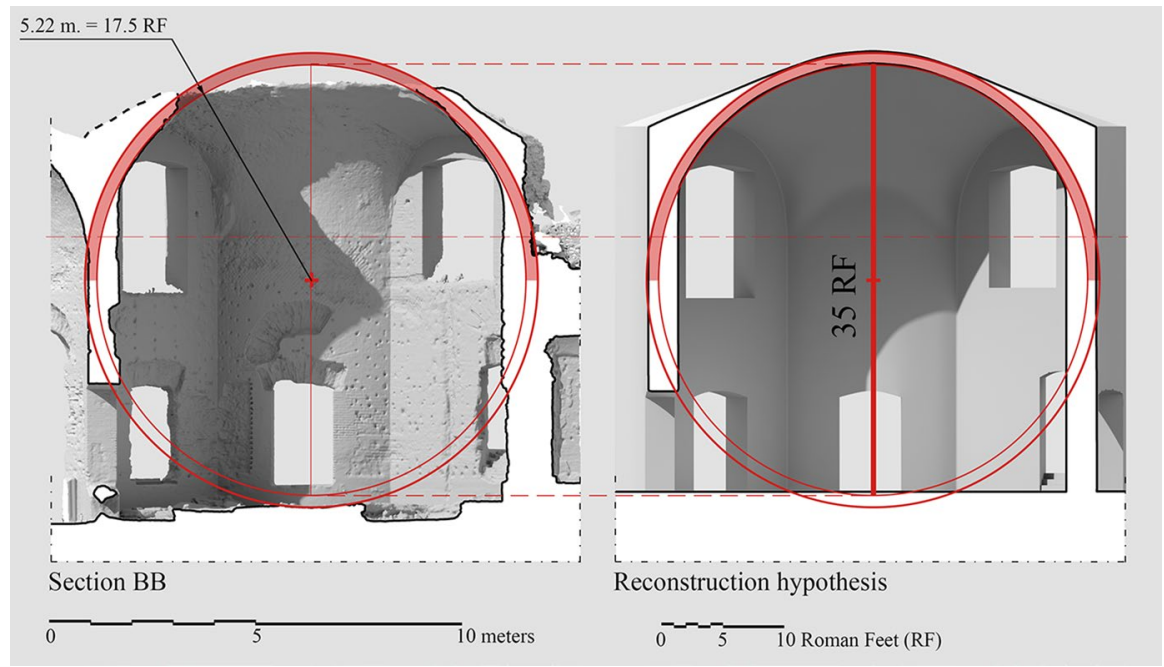

Fig. 8 Octagonal Hall at Small Baths: simple ratios linking plan and elevation (7 modules of 5 Roman feet). The supposed thickness of the spherical cap is 1 Roman foot

volume: a diameter of 7 modules (10.44 m, corresponding to 35.31 Roman feet) equal to the side of the square defining the plan (Fig. 8).

This first example shows the presence of a modular grid, but the specific conditions of the building make it complex to determine the radii $\left(\mathrm{R}_{\mathrm{i}}, \mathrm{R}_{\mathrm{e}}\right)$ and thickness $(\mathrm{T})$ of the dome at the base of the drum. In any case, the available data show that the summit would most likely have ended in a spherical cap formed, by approximation, of 12 cylindrical segments on the model of the Octagonal Hall at the Domus Aurea. ${ }^{10}$ Due to a cocciopesto coating, it is difficult to determine the geometrical law by which the drum's mixtilinear octagon became a sphere, but ongoing restorations of the complex will provide more information on this aspect.

It is now useful to conduct an analysis in parallel with the vestibule of the Golden Court. This is an independent volume, unlike the Octagonal Hall of the Small Baths but, upon a more analytic look, they are seen to share several features.

First, the Golden Court presents a grid-based design, clearly underlined by the rhythm of brick columns leaning against the perimeter walls of the peristyle (Fig. 9). Axial spacing varies significantly as shown in Table 2.

It should be noted that this fractional measurement is particularly awkward if considered as a simple linear module. But from the point of view of the grid-based design, a square with a side of between 5.47 and 5.48 Roman feet has an area of about 30 square Roman feet: a clear advantage when calculating building elements and other requirements. In addition, this "ambiguous" module $(u)$ has a further

\footnotetext{
${ }^{10}$ Cipriani et al. (2017) proposed this interpretation scheme in line with the graphic hypothesis on the Octagonal Hall of the Domus Aurea by Lynne C. Lancaster (2005: 43).
} 


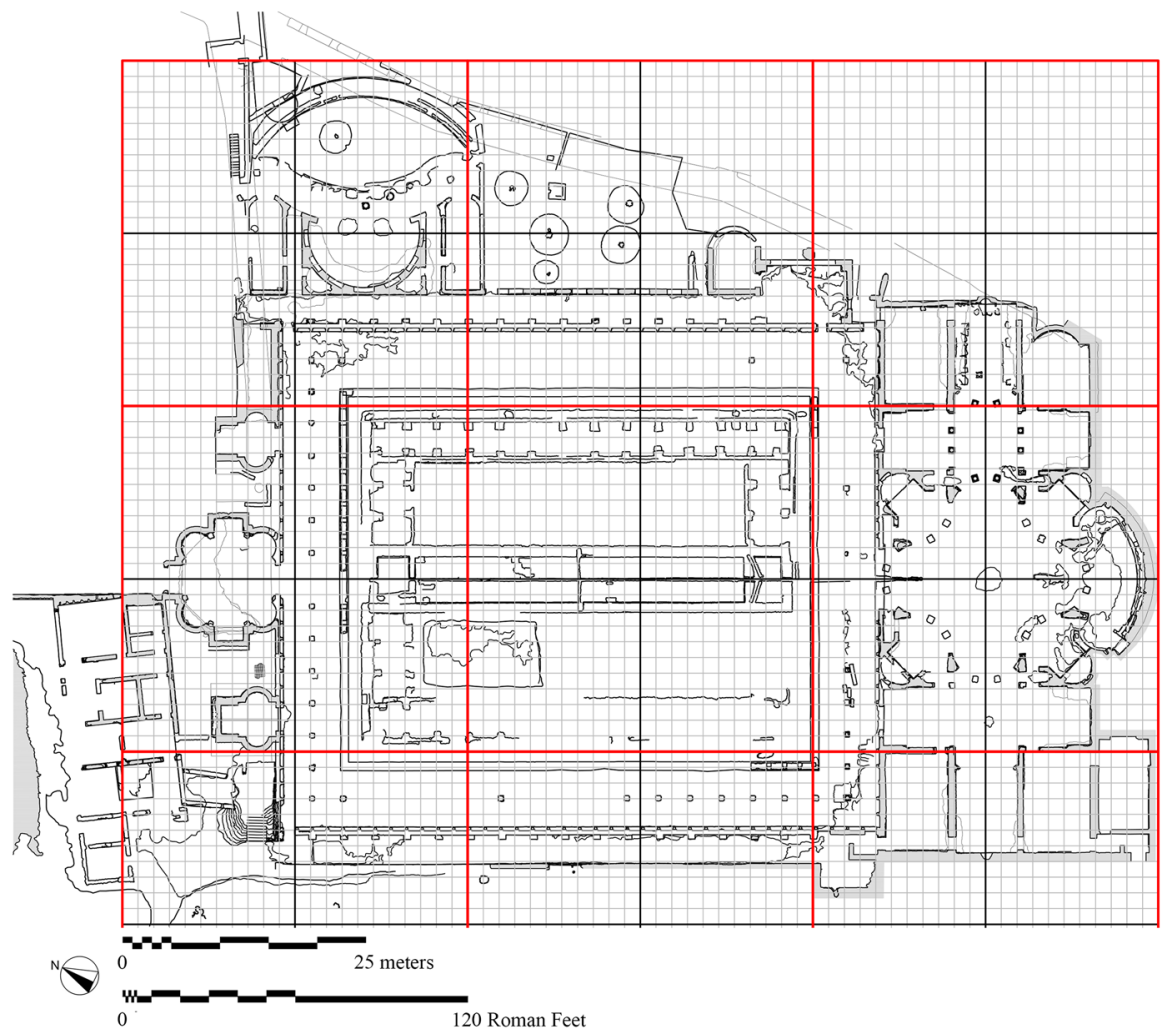

Fig. 9 Grid-based design of Golden Court's peristyle. In red the actus $(120 \times 120=14,400$ square Roman feet); black sub-grid defines the clima $(60 \times 60=3,600$ square Roman feet)

Table 2 Centre to centre distances of Golden Court columns

\begin{tabular}{ll}
\hline Side & $\begin{array}{l}\text { Average measure } \\
\text { in Roman feet }\end{array}$ \\
\hline North & 5.51 \\
West & 5.31 \\
South & 5.47 \\
East & 5.48 \\
Average & 5.44
\end{tabular}

advantage since it links the measure of 120 Roman feet to the formulas containing the constant $\pi(22 / 7)$ :

$$
\mathrm{u}=\frac{120}{22}=\frac{60}{11}=5 . \overline{45} \text { Roman feet; } \mathrm{u}^{2} \simeq 30 \text { square Roman feet }
$$

This building is expressive of a clear desire to demonstrate the structural strength of opus ceamenticium, so over the years has been studied by numerous scholars. One 


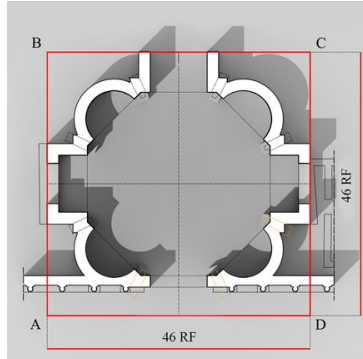

(a)

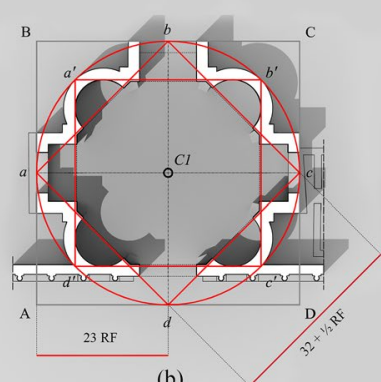

(b)

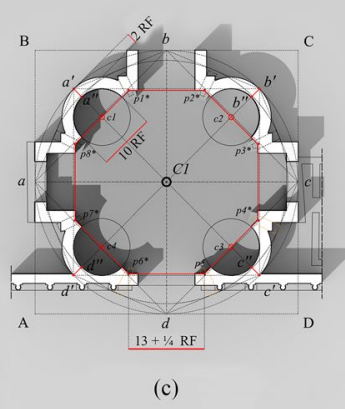

(c)

Fig. 10 Vestibule of the Golden Court: a global dimensioning; b idealised geometric hypothesis for the definition of the centrally-planned layout; $\mathbf{c}$ measurements of real elements (RF=Roman foot/feet)

among them, Cairoli Giuliani (1975: 21), hypothesised that the section of the loadbearing brick pillars of the Vestibule were the product of some sort of "geometric dimensioning".

On the basis of the reality-based model it is possible to observe that:

- The overall dimensioning of the pavilion is based on a square (ABCD), which sides are equal to 46 Roman feet (Fig. 10a).

- The internal and external walls are arranged in two squares $a b c d$ and $a^{\prime} b^{\prime} c^{\prime} d^{\prime}$, mutually rotated $45^{\circ}$ and inscribed in the circle with a diameter of 46 Roman feet (Fig. 10b).

- The thickness of the walls is dimensioned ad abundantiam to 2 Roman feet except for corner pillars.

- Brick pillars supporting the travertine pulvins of the Vestibule are thicker and regularly arranged on six of the eight points onto which the large dome transmits its weight. The exception is the side of the octagon adjacent to the portico: here they present a different shape of the resistant section so as not to alter the continuity of the peristyle. ${ }^{11}$

- The elementary geometric constructions described so far lead to the following measures of the octagon: internal sides equal to $3.92 \mathrm{~m}$., or 13.25 Roman feet, niche openings 10 Roman feet (Fig. 10c).

Before focusing on the Vestibule's orthographia, it is necessary to deal with two topics that help to understand the reasons for its dimensioning: the elevation of the peristyle and the East triclinium of the Golden Court. The grid-based design also extends to the elevation of the complex, as it emerges from the more preserved facade of the peristyle in the South-East corner (Fig. 11).

\footnotetext{
11 As at the Small Baths, the architects tried to solve problems concerning weakened structural parts through some sort of "palliative", namely, thickening of the walls. However, these solutions did not prevent the collapse of the southern portion of the Vestibule dome (see Fig. 4).
} 


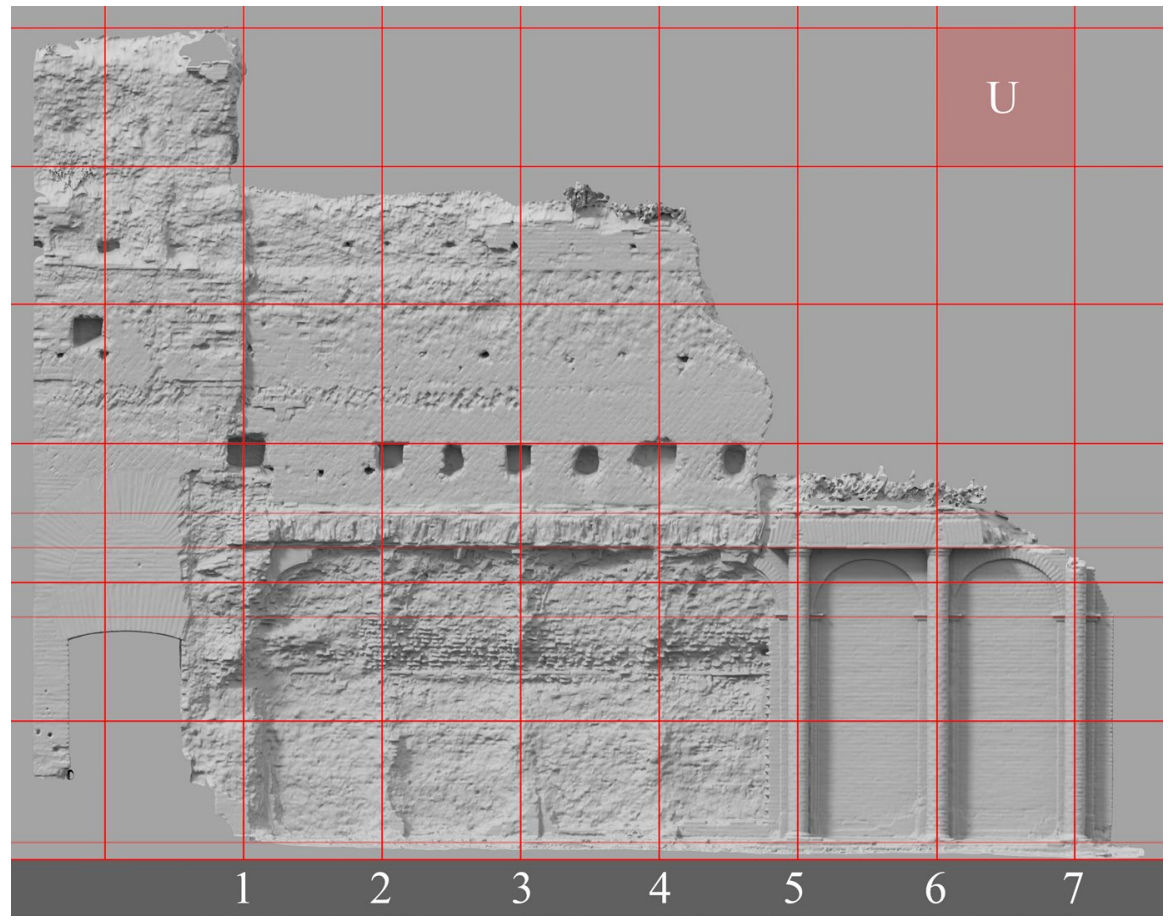

Fig. 11 Façade design of the Golden Court
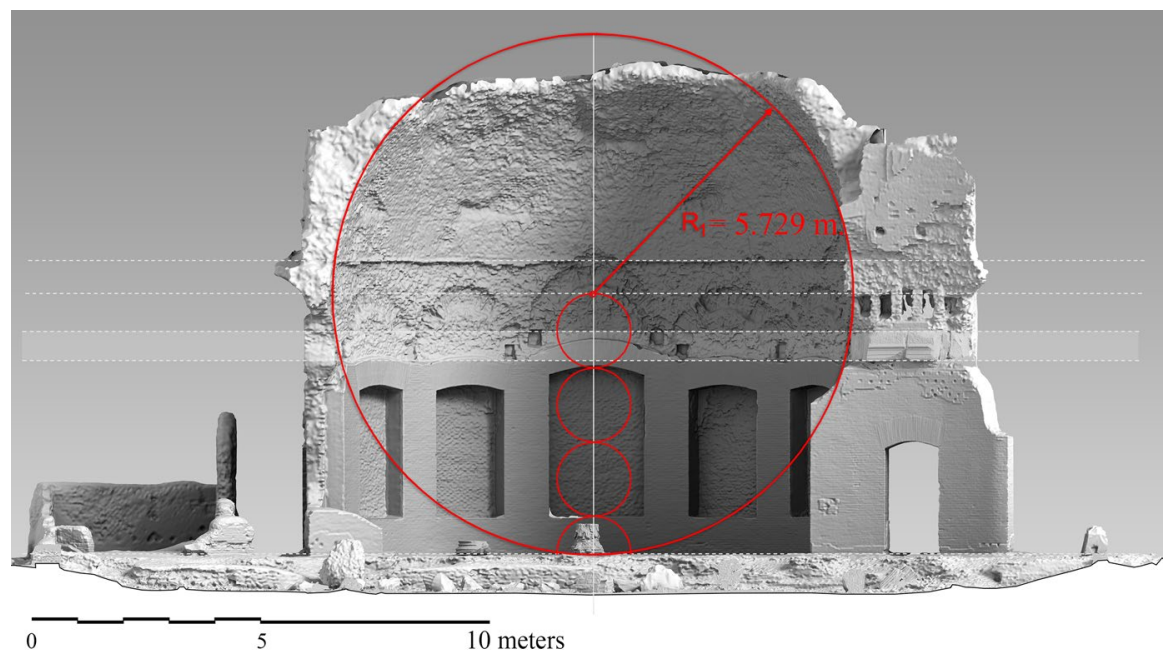

Fig. 12 East triclinium at Golden Court: the hemispherical dome presents a consistent modularity with the rest of the structures belonging to this pavilion. 7 modules are present in the intrados 


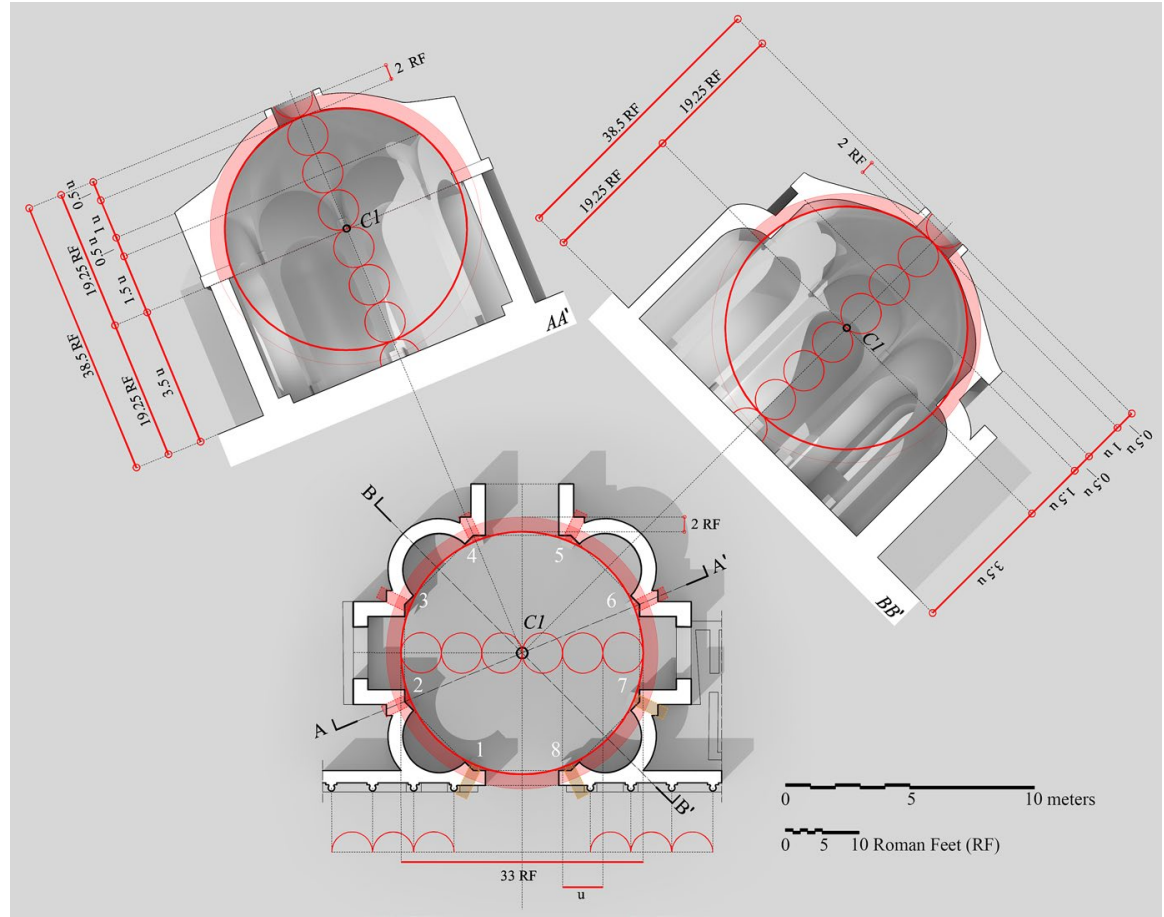

Fig. 13 Design analysis of the Vestibule. In this case 7 modules are present in the extrados diameter

Table 3 Radii extracted with vertical planes passing through opposite preserved travertine pulvins (white numbers in Fig. 13)

\begin{tabular}{llllll}
\hline Pulvins & $\mathrm{R}_{1}(\mathrm{~m})$ & $\begin{array}{l}\mathrm{R}_{1} \text { (module } \mathrm{u}=5.51 \\
\text { Roman feet) }\end{array}$ & $\mathrm{R}_{2}(\mathrm{~m})$ & $\mathrm{T}(\mathrm{m})$ & $\mathrm{T}$ (Roman feet) \\
\hline $1-5$ & 4.980 & 3.057 & 5.578 & 0.598 & 2.023 \\
$2-6$ & 4.900 & 3.007 & 5.491 & 0.591 & 1.999 \\
$3-7$ & 4.850 & 2.977 & 5.520 & 0.670 & 2.266 \\
$4-8$ & 4.975 & 3.054 & 5.610 & 0.635 & 2.148 \\
\hline
\end{tabular}

The Vestibule does not present a 1:1 ratio linking ichnographia and orthographia, but to the east there is a triclinium space with a hemispherical dome that respects this base-to-height relation. This building, located in the north-east corner of the peristyle has a clear relation linking plan and façade (Fig. 12): the radius $R_{1}$ of the central space is equal to 5.729 m., consistent with the module (u) of 5.48 Roman feet present on that side of the portico (Table 2):

$$
\mathrm{R}_{1}=3.5 \mathrm{u} \times 5.48 \text { Roman feet }=5.669 \mathrm{~m} . \approx 5.729 \mathrm{~m} .
$$




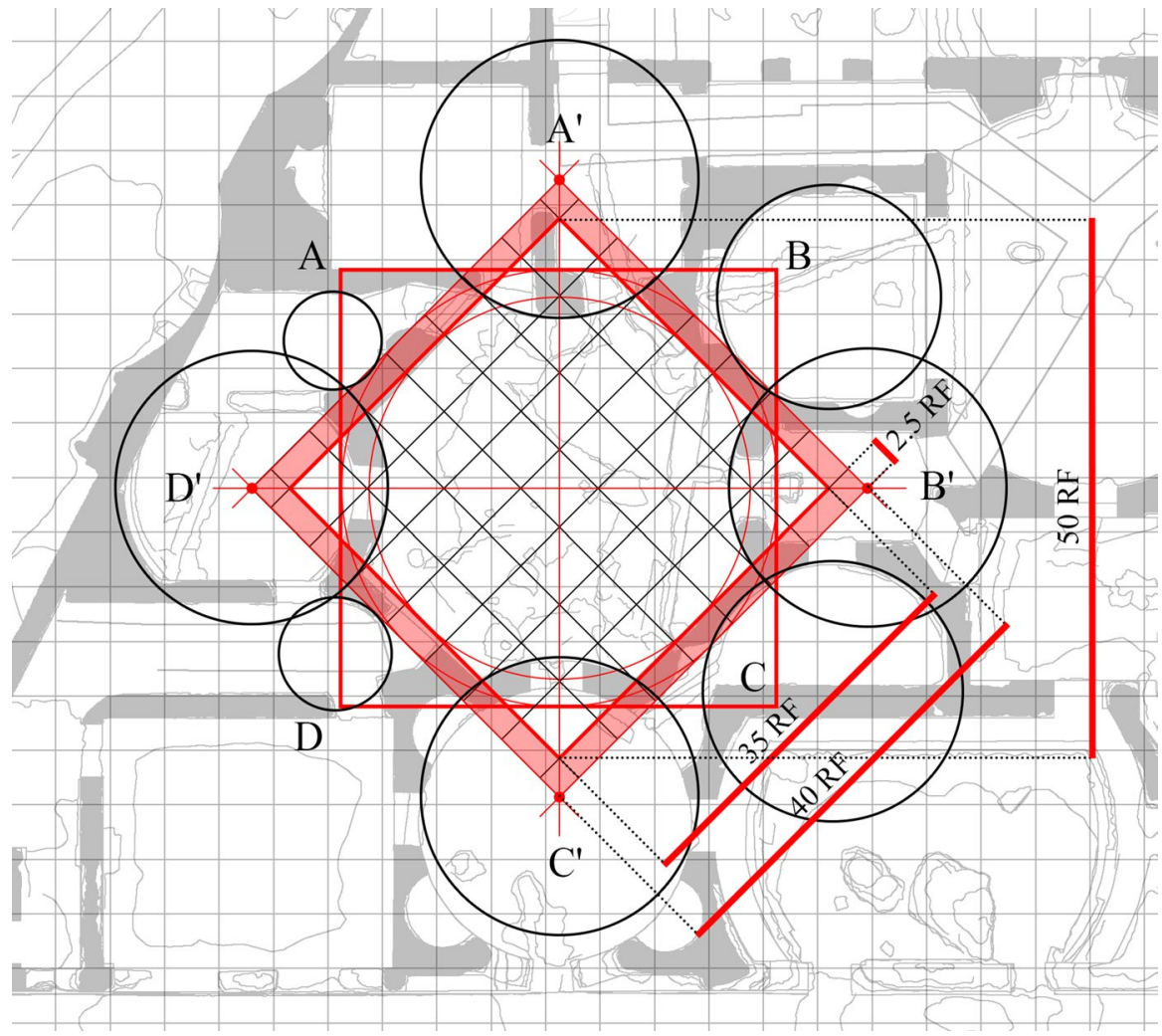

Fig. 14 Small Baths' dimensioning of the Octagonal Hall. Dimensions in Roman feet (RF)

In Fig. 13 a possible interpretation of the ichnographia-orthographia relationship of the vestibule at the Golden Court is shown. The dome is smaller than the one of the triclinium since the average radius of $R_{1}$ of the sphere is equal to 3 modules of 5.51 Roman feet, as can be extrapolated from the data shown in Table 3, in which the radii of the circumferences, as well as $R_{2}$ and $T$, are found through reverse modelling techniques.

The average thickness of the dome is around 2 Roman feet (more precisely, 2.109 Roman feet) when cutting the dome along the pulvins. Two observations arise from this: the first is that the thickness is slightly higher because of the cocciopesto coating, the second is that it does not seem consistent with the modular logic of the rest of the composition. Applying the sequence of Eqs. (3)-(6) above we obtain that the volume of hollow semi-sphere, which, without adding or subtracting other elements of the structure, is equal to $3,790.23$ cubic Roman feet. 


\section{Conclusions}

The comparison between the two domes has allowed us to find a series of common elements that, compared to previous studies, sheds new light on the more complex of the two cases, the Octagonal Hall of the Small Baths: how did ancient architects determine the wall thickness?

As well as for the octagonal Vestibule, the composition starts with a square ABCD that inscribes the octagonal room (Fig. 14): its sides are consistent with the overall grid of 5 Roman feet of the Small Baths, being the total length of the side 8 modules, therefore equal to 40 Roman feet. This square includes the entire thickness of the masonry on which the dome relieves its weight. The graphic algorithm is similar to the other building: in particular, applying a $45^{\circ}$ rotation to the square of 40 Roman feet, we obtain $\mathrm{A}^{\prime} \mathrm{B}^{\prime} \mathrm{C}^{\prime} \mathrm{D}^{\prime}$ whose sides are tangent to other circular volumes surrounding the octagon. In addition, the vertices of this square are close to the centres of the circumferences that determine the curved sides of the internal profile of the octagonal space. Internal straight profiles are based on a rotated grid of 7 modules of 5 Roman feet each, and the thickness of the walls is equal to 2.5 Roman feet (half a module). According to this new hypothesis, the radii of curvature that give rise to the curved sides measure 2.5 modules of 5 Roman feet, or 12.5 Roman feet $(3.695 \mathrm{~m})$.

The design of the domes involved a great effort in terms of drawing and calculation and required from the very beginning a perfect consistency with the modular grid of the entire building. This grid was meticulously determined in order to facilitate the calculations involving the $\pi$. Therefore, paradoxically, we can find irrational modules obtained by dividing whole numbers of Roman feet by 11 . At the same time, the architects used quantities of modules in relation to the number 7 to dimension the radius of the dome. Everything was functional to simplify multiplication by $22 / 7$.

Moreover, the modules are always to be considered as surface units rather than simple linear measurements: also in this case the aim was to use standard measurements such as those of clima $(60 \times 60=3,600$ square Roman feet) and actus $(120 \times 120=14,400$ square Roman feet) (see Fig. 9).

Ongoing restorations of Hadrianic domes will certainly allow a deeper understanding of the complex relationship between intrados and extrados; however, it is safe to affirm that even the apparently more complex shapes ended in spherical caps: in the current state of our knowledge, surfaces connecting the lunettes and the spherical top were designed through a tangency relationship that now is still difficult to understand, but was certainly present.

The next phases of the ongoing analysis will extend to other Hadrianic buildings, hand in hand with a critical study of the writings of Hero and Archimedes. The goal is to obtain a clearer and more complete picture of the relationship between architectural culture and the exact sciences, following the example of recent studies on Baroque architecture that present a comparative reading of digital surveys and theoretical treaties (Spallone 2018). 
Acknowledgements Open access funding provided by Alma Mater Studiorum-Università di Bologna within the CRUI-CARE Agreement. All authors contributed to the paper writing, digital surveys and data gathering. Luca Cipriani is the coordinator of the surveying activities at Hadrian's Villa and author of abstract and "Aims of Recent Surveys". Filippo Fantini designed active and passive sensor integration for the survey of the domes and is author of "Approach to the Problem" and "From Survey to Design: Differences and Common Features". Silvia Bertacchi developed 2D and 3D graphic output methodologies and conceptual schemes and is author of Sects. "An Increasing Will to Experiment" and "Conclusions". All authors read and approved the final manuscript. All images, 3D models and digital elaborations, unless otherwise specified, are by authors.

Open Access This article is licensed under a Creative Commons Attribution 4.0 International License, which permits use, sharing, adaptation, distribution and reproduction in any medium or format, as long as you give appropriate credit to the original author(s) and the source, provide a link to the Creative Commons licence, and indicate if changes were made. The images or other third party material in this article are included in the article's Creative Commons licence, unless indicated otherwise in a credit line to the material. If material is not included in the article's Creative Commons licence and your intended use is not permitted by statutory regulation or exceeds the permitted use, you will need to obtain permission directly from the copyright holder. To view a copy of this licence, visit http://creativeco mmons.org/licenses/by/4.0/.

\section{References}

Adembri, Benedetta, Adolfo Alonso-Durá, Francisco Juan-Vidal, Gianna Bertacchi, Silvia Bertacchi, Luca Cipriani, Filippo Fantini, and Beatriz Soriano-Estevalis. 2016. Modelli digitali 3D per documentare, conoscere ed analizzare l'architettura e la costruzione nel mondo antico: l'esempio della Sala Ottagonale delle Piccole Terme di Villa Adriana. Archeologia e Calcolatori. https://doi.org/10.19282 /AC.27.2016.15.

Adembri, Benedetta, Luca Cipriani, Filippo Fantini and Silvia Bertacchi. 2015. Reverse designing: an integrated method for interpreting ancient architecture. SCIRES-it. https://doi.org/10.2423/i22394303v $5 \mathrm{n} 2 \mathrm{p} 15$.

Bianchini, Carlo and Filippo Fantini. 2015. Dimensioning of Ancient Buildings for Spectacles Through Stereometrica and De mensuris by Heron of Alexandria. Nexus Network Journal. https://doi. org/10.1007/s00004-014-0230-8.

Boyer, Carl B. 2000. Storia della Matematica. Milano: Arnoldo Mondadori Editore.

Brown, Frank E. 1964. Hadrianic Architecture. In Essays in Memory of Karl Lehmann, ed. Lucy Freeman Sandler, 55-58. New York: Institute of Fine Arts, New York University.

Cinque, Giuseppina Enrica and Elisabetta Lazzeri. 2011. Analisi geometriche e progettuali in alcuni complessi di Villa Adriana. Romula 1: 55-83.

Cipriani, Luca. 2018. Le attività di rilevamento a Villa Adriana: il ruolo delle nuove tecnologie. Ananke Speciale 84 Villa Adriana: 116-120.

Cipriani, Luca, Filippo Fantini and Silvia Bertacchi. 2017. The Geometric Enigma of Small Baths at Hadrian's Villa: Mixtilinear Plan Design and Complex Roofing Conception. Nexus Network Journal. https://doi.org/10.1007/s00004-017-0344-x.

Conti, Cinzia and Giangiacomo Martines. 2010. Hero of Alexandria, Severus and Celer: Treatises and Vaulting at the Nero's Time. In Mechanics and Architecture between Epísteme and Téchne, ed. Anna Sinopoli, 79-96. Roma: Edizioni di Storia e Letteratura.

De Angelis D’Ossat, Guglielmo. 1938. Sugli edifici ottagonali a cupola nell'antichità e nel Medio Evo. In Atti del I Congresso Nazionale di Storia dell'Architettura (Firenze, 29-31 Ottobre 1936 XV), 13-24. Firenze: G.C. Sansoni.

Frajese, Attilio. 1974. Opere di Archimede. Torino: UTET.

Giuliani, Cairoli Fulvio. 1975. Il lato nord ovest della Piazza d'Oro. In Ricerche sull'architettura di Villa Adriana. Quaderni dell'Istituto di Topografia antica dell'Università di Roma, eds. Cairoli Fulvio Giuliani and Patrizia Verduchi, 3-53. Roma: De Luca.

Hansen, Erik. 1960. La "Piazza d'Oro" e la sua cupola. Analecta Romana Instituti Danici I Supplementum. Copenhagen: Einar Munksgaard.

Heiberg, Johan Ludvig. 1914. Heronis Alexandrini, Opera quae supersunt omnia. Stuttgart: Teubner (rpt. 1976). 
Lancaster, Lynne C. 2005. Concrete Vaulted Construction in Imperial Rome: Innovations in Context. Cambridge: Cambridge University Press.

MacDonald, William L. and Bernard M. Boyle. 1980. The Small Baths at Hadrian's Villa. Journal of the Society of Architectural Historians 39(1): 5-27.

Martines, Giangiacomo. 2014. Isidore's Compass. A Scholium by Eutocius on Heron's Treatise on Vaulting. Nuncius: annali di storia della scienza 29(2): 279-311.

Martines, Giangiacomo. 2015. The Conception and Construction of Drum and Dome. In The Pantheon: From Antiquity to the Present, eds. Tod A. Marder and Mark Wilson Jones, 99-131. Cambridge: Cambridge University Press.

Moneti, Andrea. 1992. Nuovi sostegni all'ipotesi di una grande sala cupolata alla "Piazza d'Oro", Analecta Romana Instituti Danici 20: 67-92.

Ottati, Adalberto. 2017. Costruzione e ricostruzione dell'Accademia di Villa Adriana: dall'analisi del monumento alla restituzione. Problemi e soluzioni nell'uso della tecnologia digitale. Archeologia $e$ Calcolatori. https://doi.org/10.19282/AC.28.1.2017.11.

Ottati, Adalberto, Silvia Bertacchi and Benedetta Adembri. 2018. Integrated methods for documentation and analysis of archaeological heritage: the residential building along the western side of the Canopus at Hadrian's Villa. Initial results and research perspectives. SCIRES-it. https://doi.org/10.2423/i2239 $4303 \mathrm{v} 3 \mathrm{n} 2 \mathrm{p} 85$.

Rakob, Friedrich Ludwig. 1967. Die Piazza d'Oro in der Villa Hadriana bei Tivoli. Ph.D thesis, University of Munich.

Slavazzi, Fabrizio. 2014. Piazza d'Oro a Villa Adriana: architettura e meraviglia. In Adriano e la Grecia: Villa Adriana fra classicità ed ellenismo. Studi e ricerche, eds. Elena Calandra and Benedetta Adembri, 71-80. Milano: Electa.

Spallone, Roberta. 2018. Geometry, Arithmetic, Architecture. Calculation Methods for Vault Surfaces in the Modo di Misurare le Fabriche by Guarini. In ICGG 2018-Proceedings of the 18th International Conference on Geometry and Graphics (Milan, Italy, 3-7 August 2018), 2108-2119. Springer.

Svenshon, Helge. 2009. Heron of Alexandria and the Dome of Hagia Sophia in Istanbul. In Proceedings of the Third International Congress on Construction History (Brandenburg University of Technology Cottbus, Germany, 20-24 May 2009), 1387-1394. Berlin: NEUNPLUS1.

Wilson Jones, Mark. 2000. Principles of Roman Architecture. New Haven: Yale University Press.

Publisher's Note Springer Nature remains neutral with regard to jurisdictional claims in published maps and institutional affiliations.

Luca Cipriani Associate Professor of Architectural Representation at the University of Bologna. He received a $\mathrm{PhD}$ in Civil Engineering and attended the VIII cycle of Research Doctorate in Engineering, Building and Territorial at the Faculty of Engineering, University of Bologna, 1996. Investigation lines: study of the process of urban development, procedures and techniques of digital survey and 3D modelling of monuments and heritage. The research activity is documented by publications in peer reviewed journals and conference proceedings: Disegnare idee immagini, Parametro, Paesaggio urbano, VSMM, ISPRS, EGA Revista de expresión gráfica arquitectónica, International Conference of Education, INTED International Technology, Urban Data Management Symposium, Forum UNESCO, SPIE, SIGRADI. He has written several books among them: "The design of the portico of San Luca in Bologna" and "Examples of architectural design. The teaching of drawing in the Faculty of Engineering of Bologna".

Filippo Fantini Associate Professor at the Department of Architecture DA of the Alma Mater Studiorum-University of Bologna, has achieved a Ph.D. in Science of Surveying and Representation of Architecture and Environment at the University of Florence with a thesis on an ancient marble model from Hadrian's Villa. From 2009 to 2011 he had the scholarship "Santiago Grisolia" at the Instituto de Restauración del Patrimonio (IRP) of the Polytechnic University of Valencia focussed on Ancient Greek and Roman Theatres: from their survey to their current utilisation and management. Current projects are focused on design analysis of vaulted spaces carried out using digital surveying techniques, 3D Modelling, Procedural and Reverse Modelling. 
Silvia Bertacchi Graduated with first-class honours at the University of Florence in 2009. She is an architect with a European $\mathrm{PhD}$ in the Science of Surveying and Representation of Architecture and Environment at the Department of Architecture, University of Florence. Since the academic year 2013/2014 she was adjunct professor in several Italian universities (University of Bologna, Firenze, Ferrara and Pavia) and has also lectured abroad (Estonian Academy of Arts EKA). At present she is research fellow at the Department of Architecture of the University of Bologna with a project for the digital documentation and representation systems of minor historic centres. Her research is mainly focused on descriptive geometry, design, architecture and computer graphics and their application on architecture and cultural heritage. 